
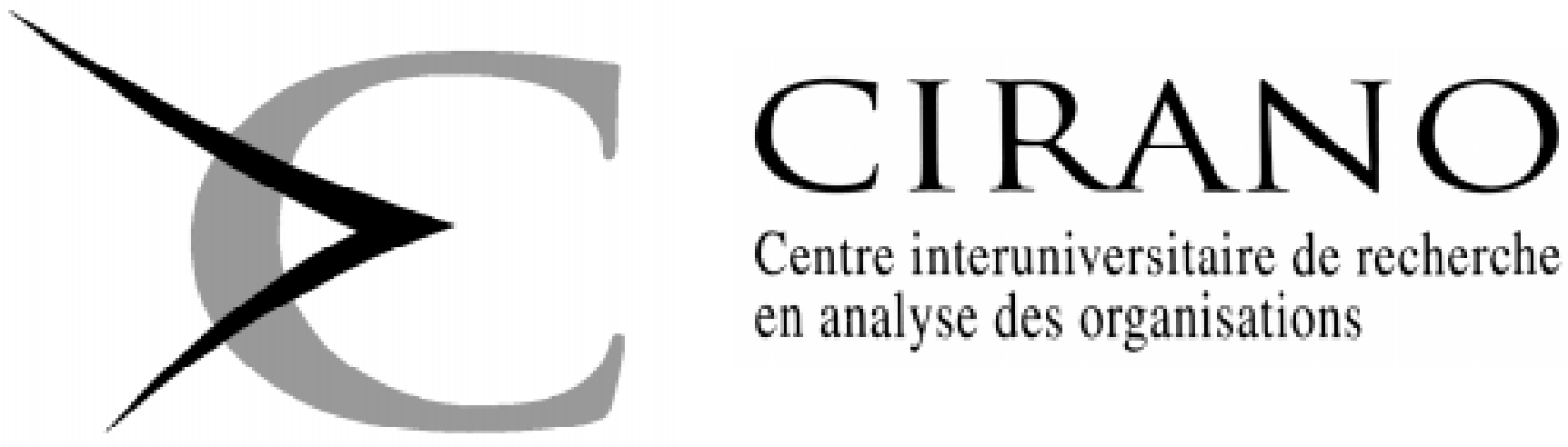

Centre interuniversitaire de recherche en analyse des organisations

Série Scientifique

Scientific Series

98s-09

Managerial Career Success in

Canadian Organizations:

Is Gender a Determinant?

Denis Chênevert, Michel Tremblay 


\section{CIRANO}

Le CIRANO est une corporation privée à but non lucratif constituée en vertu de la Loi des compagnies du Québec. Le financement de son infrastructure et de ses activités de recherche provient des cotisations de ses organisations-membres, d'une subvention d'infrastructure du ministère de l'Industrie, du Commerce, de la Science et de la Technologie, de même que des subventions et mandats obtenus par ses équipes de recherche. La Série Scientifique est la réalisation d'une des missions que s'est données le CIRANO, soit de développer l'analyse scientifique des organisations et des comportements stratégiques.

CIRANO is a private non-profit organization incorporated under the Québec Companies Act. Its infrastructure and research activities are funded through fees paid by member organizations, an infrastructure grant from the Ministère de l'Industrie, du Commerce, de la Science et de la Technologie, and grants and research mandates obtained by its research teams. The Scientific Series fulfils one of the missions of CIRANO: to develop the scientific analysis of organizations and strategic behaviour.

\section{Les organisations-partenaires / The Partner Organizations}

-École des Hautes Études Commerciales

-École Polytechnique

-McGill University

- Université de Montréal

-Université du Québec à Montréal

-Université Laval

-MEQ

- MICST

-Avenor

- Banque Nationale du Canada

-Bell Québec

- Caisse de dépôt et placement du Québec

- Fédération des caisses populaires Desjardins de Montréal et de l'Ouest-du-Québec

-Hydro-Québec

- Industrie Canada

- Microcell Labs inc.

- Raymond, Chabot, Martin, Paré

- Scetauroute

- Société d'électrolyse et de chimie Alcan Ltée

-Téléglobe Canada

-Ville de Montréal

Ce document est publié dans l'intention de rendre accessibles les résultats préliminaires de la recherche effectuée au CIRANO, afin de susciter des échanges et des suggestions. Les idées et les opinions émises sont sous l'unique responsabilité des auteurs, et ne représentent pas nécessairement les positions du CIRANO ou de ses partenaires.

This paper presents preliminary research carried out at CIRANO and aims to encourage discussion and comment. The observations and viewpoints expressed are the sole responsibility of the authors. They do not necessarily represent positions of CIRANO or its partners.

ISSN 1198-8177 


\title{
Managerial Career Success in Canadian Organizations: Is Gender a Determinant?*
}

\author{
Denis Chênevert ${ }^{\dagger}$, Michel Tremblay ${ }^{\ddagger}$
}

Résumé / Abstract

Cette étude analyse l'influence du sexe des gestionnaires sur quatre mesures objectives du succès de carrière. Après avoir contrôlé le capital humain, le contexte familial, l'origine socio-économique, les valeurs et motivations et les variables structurelles, le fait d'être un homme ou une femme continue d'exercer un effet sur deux des quatre mesures utilisées : le niveau de salaire et le niveau hiérarchique.

This study examines the influence of gender on four objective aspects of career success. After controlling human capital, family context, socioeconomic origin, values and motovations, as well as structural variables, gender continues to have an effect on two of the four aspects: salary and hierarchical level.

Mots Clés : $\quad$ Carrière, succès, femmes, gestionnaires

Keywords : $\quad$ Career, success, gender, managers

\footnotetext{
* Corresponding Author: Michel Tremblay, CIRANO, 2020 University Street, 25th floor, Montréal, Qc, Canada H3A 2A5 Tel: (514) 985-4000 Fax: (514) 985-4039 e-mail: tremblam @ cirano.umontreal.ca

${ }^{\dagger}$ École des Hautes Études Commerciales

* École des Hautes Études Commerciales and CIRANO
} 


\section{Introduction}

Women are increasingly present on the labor market, and by the end of the $1980 \mathrm{~s}$ accounted for nearly $43 \%$ of the working population (Pigeon, 1988). In the last decade they have also made significant progress in the managerial function. In fact, women are no longer confined to lower-level positions in the organizational hierarchy, and now hold more than $40 \%$ of all managerial jobs (Jacobs, 1992). However, although female managers have high levels of education and a desire to progress in their careers, few achieve the same status or salary as their male counterparts (Stroh et al., 1992). Why is this so?

A number of different approaches have been used to attempt to explain the malefemale differential in career success. These include the theory of human capital (Becker, 1975), based on the personal investment made by individuals in their own education, work experience, training, etc., which has been used by some researchers to explain the differences observed (Hersch, 1991; Jaskolka et al., 1985). Family context has also been considered as an explanatory factor. Men and women do not face the same family constraints, and this appears to have an impact on their career success (Tharenou et al., 1994; Cannings, 1991; Gattiker and Larwood, 1990). Other researchers have proposed socioeconomic origins rather than personal skills to explain individual career paths. However, the influence of this factor seems to differ between the sexes (Featherman and Hauser, 1976). Some researchers have examined the problem from the standpoint of values and motivations at work (Jaskolka et al., 1985). Male values and motivations seem to be closer to those held by enterprises (Markham, 1987; Stewart and Gudykunst, 1982). Finally, some structural barriers also seem to have an effect on the career success of female managers (Blum et al., 1994; Groshen, 1990), and certain organizational and sector-based factors appear to explain gender-based differences in career success (Cannings, 1991; Hannan et al., 1990).

The different career theories reveal the existence of two separate perspectives of career success: the internal perspective and the external perspective (Gattiker and Larwood, 1990; Derr, 1986; Van Maanen and Schein, 1977). The former refers to the subjective aspect of success, i.e. the individual perception. Here, success can be assessed only by taking account of the person making the assessment and the criteria that he or she uses (Derr and Laurent, 1989). The latter refers to the objective aspect of success, i.e. a social vision of success in which career advancement is considered to be the key element. Career advancement can be represented by a single criterion (e.g. salary) or by several criteria (e.g. salary, hierarchical level, number of people managed, etc.). 
In this paper, we will use a multi-criteria external (objective) perspective to define career success. We have based our choice on the fact that the external perspective is still the most widely used in Western societies. However, most of the studies that have used this perspective so far have included only one or two criteria, thus reducing the scope of the variable to be explained. In this research, we will use four criteria: salary, hierarchical level, number of promotions and speed of promotion.

In the research, we will attempt to define and analyze the elements explaining managerial career advancement and to establish the extent to which gender influences advancement. In particular, we will be looking at the explanatory power of human capital theory, family context, socioeconomic origin, individual values and motivation and structural factors with respect to salary, hierarchical level, number of promotions and speed of promotion of male and female managers. The goal of the study is therefore to identify and understand the career advancement determinants for Canadian managers and to see whether or not gender is a significant explanatory factor.

\section{Hypotheses and Theoretical Framework}

Hypothesis 1: Women have a lower level of career success than men in terms of salary, hierarchical level, number of promotions and speed of promotion.

Many different studies have supported this hypothesis, demonstrating a significant career success differential between men and women (Stroh et al., 1992; Cannings, 1991, 1988; Dipboye, 1987; Eberts and Stone, 1985). In fact, men and women do not always begin with the same attributes, and even when they do, they nevertheless achieve different levels of objective career success. Women seem to face obstacles unrelated to their professional duties and responsibilities, which are detrimental to their career development (Ohlott et al., 1994). Role socialization conditions women to accept certain responsibilities outside their work, from which men are exempt. Overall, these constraints often force women into what is known as the "mommy track", i.e. career paths reserved exclusively for women (Konrad and Cannings, 1991). These paths contain low profile positions offering few challenges, thus reducing the opportunities for promotion and creating a vicious circle in which women have little chance of pushing their way through the glass ceiling (Tharenou et al., 1994; Ohlott et al., 
1994).

\section{Hypothesis 2: The difference in the career success of male and female managers is a result of the human capital theory.}

The human capital theory suggests that the individuals who invest the most in their own education, training, experience, etc. are those who obtain the most career options (Becter, 1975). In fact, human capital variables may explain as much as 30\% of the variation in salary (Medoff and Abraham, 1980; Jaskolka et al., 1985; Cannings, 1988a) and hierarchical level (Jaskolka et al., 1985; Johnsrud, 1991). Very little work has been done on the effect of human capital on the number and speed of promotions. However, Stewart and Gudykunst (1982) concluded that human capital may explain up to $47 \%$ of the variation in the number of promotions obtained by men, but only $25 \%$ for women.

Human capital may thus have a more significant impact on career success among men than among women. Hersch (1991) found that this category of variable explained up to $30 \%$ of the male-female salary differential. In fact, some studies have shown that women, because of their family responsibilities, are absent from work more often than their male counterparts, thus reducing the professional value of their human capital.

Of all the variables used to measure human capital, education seems to have attracted the most attention from researchers, since it has a significant influence on career success (Tharenou et al., 1994). It would therefore be reasonable to believe that the lower level of education among women in general will prejudice their chances of career advancement quite considerably.

Similarly, the frequency with which female managers change employers in an attempt to solve problems of discrimination has the effect of limiting their experience within a given organization (Neumark and McLennan, 1994). The resulting low level of seniority reduces their chances of entering influential networks and, consequently, their chances of achieving higher levels of career success.

To test this hypothesis, we will use two independent variables: level of education and number of employers. Other variables traditionally associated with human capital, such as work experience and seniority with the organization, have been used in this study as control variables. 


\section{Hypothesis 3: The difference in the career success of male and female managers is a result of the family context.}

The theory of family context suggests that the family environment in which men and women live may have a significant impact on their career success. Generally speaking, men seem to be favoured and women penalized by the features of the family context.

For example, men seem to benefit more from marriage than women. According to Pfeffer and Ross (1982), a married woman who does not participate actively in the labour market is considered to be an additional resource for her spouse, enabling him to invest more in his career. The reverse, however, does not seem to hold true.

Some studies have shown that the number of dependent children has a positive impact on career advancement for men, and a negative impact for women. Hersch (1991) suggested that the number of children affects the behaviour of men, among other things by increasing their motivation for, involvement in and commitment to their work. In contrast, the size of the family seems to have a negative effect on the career advancement of women, because women are forced by social, structural or personal factors to devote more time than men to family responsibilities (Crompton and Sanderson, 1990).

Married women with children tend to invest more in their families and less in their human capital and careers (Neumark and McLennan, 1994). The results of Tharenou et al. (1994) support this, showing that family status (married, number of children) has a negative impact $\left(-0.13^{*}\right)$ on the work experience of women and a positive impact on that of men $\left(0.11^{*}\right)$. For men, work and family are complementary, while for women they tend to be more conflictual. Lobel and StClair (1994) found that individuals who consider family-related values to be more important receive fewer salary increases based on merit and put less effort into their work than those who consider work-related values to be more important.

The third hypothesis will be tested by the following variables: family situation (living alone or married) and family responsibilities (number of dependents).

\section{Hypothesis 4: The difference in the career success of male and female managers is a result of their socioeconomic origin.}

Some studies have shown that socioeconomic origin may influence individual career success. In fact, socioeconomic origin, rather than personal skill, may influence a person's social integration within the organization and thus facilitate 
his or her career success (Cohen, 1986; Ornstein, 1983; Pfeffer and Ross, 1982; Featherman and Hauser, 1976).

According to Featherman and Hauser (1976), socioeconomic origin seems to have a greater impact on career advancement among men than among women. It is true that this category of variable is represented mainly by family social class which, in turn, depends on the father's professional status. Since men are normally influenced more by their fathers than women, this variable may therefore have a greater impact on men (Chapman, 1990). Individuals from a social class considered to be superior are motivated to maintain their advantageous position and hand it on to their children (Abbott, 1990). In fact, Abbot (1990) found that more than $50 \%$ of men but only $8 \%$ of women whose fathers came from a so-called higher social class were also in that class. Chapman (1990) showed that $70 \%$ of men but only $45 \%$ of women whose fathers worked in professional positions had jobs of equal or superior status. Women, irrespective of their social origins, thus seem to be prevented from obtaining the jobs that form part of the higher social classes.

To test this hypothesis, we will use seven variables representing the professional status of the father: farmer, non-specialized laborer, specialized laborer, office employee, professional, executive, entrepreneur.

\section{Hypothesis 5: The difference in the career success of male and female managers is a result of their personal values and motivations.}

Although very little empirical work has been done on the question, individual values and motivations nevertheless seem to explain differences in the level of career success achieved by men and women (Jaskolka et al., 1985).

Stewart and Gudykunst (1982) suggested that this category of variable has a greater impact among women than among men. A number of studies have shown that men and women hold different values and are motivated by different things (Schein et al., 1989). For example, women are more likely to conform, and are more understanding, less confident in themselves and less independent. Their ideas, attitudes and value systems are structured so as to respond to this social and cultural vision. Moreover, these factors influence certain values and motivations of women at work, such as the level of work investment and perception of fairness. (Chusmir and Durand, 1987). The fact that the values and motivations of women differ from the dominant masculine models may act as a brake upon the career advancement of female managers. Furthermore, a number 
of situational and environmental factors such as conflicts and ambiguity of roles act on organizational commitment among women (Lee et al., 1992; Pierce and Dunham, 1987).

To test our fifth hypothesis, we will use the following values and motivations: work investment and perception of the instrumental (performance/reward) link.

Hypothesis 6: The difference in the career success of male and female managers is a result of structural differences.

Structural barriers unquestionably exist, and may explain the low percentage of women in some sectors and job categories. These same barriers may perhaps explain the difference in career success among men and women. Some studies have shown that the industrial sector has an impact on individual salaries.

For example, Hannan et al. (1990) showed that the industrial sector explained 4\% of salary variation. Groshen (1990) found an $11 \%$ variation between men and women in the manufacturing sector, and $25 \%$ in the service sector. Similarly, Blum et al. (1994) showed that women held more management positions in nonmanufacturing sectors such as the public sector than in manufacturing sectors. These authors also found that female managers are more prevalent in sectors offering lower salaries.

However, the public sector may reduce some of the effects of workplace discrimination (Almquist, 1987). In fact, we need only consider the rigorous collective agreements governing the public sector, which give a certain amount of protection to minority groups.

People also tend to presume that organizational structures are sexually neutral. Yet, most commanding positions are held by men, who tend to delegate, give responsibility and accord the best promotions in terms of career advancement to men rather than women (Acker, 1990).

To test our sixth hypothesis, we will use the following variables: sector (public/private), and administrative, budgetary and supervisory responsibility.

Hypothesis 7: If hypotheses 2 to 6 do not explain the differences in the career success of male and female managers, the presence of discrimination cannot be excluded. 


\section{Methodology}

The research sample was composed of 2562 male managers and 498 female managers from 41 different organizations divided between three sectors of the Canadian economy (the pulp and paper industry, the food industry and the public and parapublic sector). The term "manager" was used to describe all employees with supervisory responsibility and those with a functional link to one or more administrative units. The data were collected by means of a questionnaire distributed by internal mail to all the managers in each organization by a resource person informed in advance of the study. The questionnaire was accompanied by an explanatory letter describing the goals of the research and guaranteeing the confidentiality of individual results. Response rates varied between $23 \%$ and $42 \%$.

For the purposes of the study, we formed two equal subsamples, composed respectively of 282 men and 282 women. The subsamples were constructed on the basis of seniority within the organization, because it would have been difficult to obtain conclusive results by comparing men and women working at different levels in the organization. After establishing the mean and standard deviation of the «SENIORITY», we selected all observations for which the value of this variable fell within a standard deviation from the mean. The new sample comprised 1431 men and 282 women. To obtain our final sample comprising equal numbers of men and women, we selected 282 of the 1431 observations at random. The two samples were then merged to form a total sample of 564 observations, 282 men and 282 women.

\section{Features of the Sample}

The male managers in our sample were slightly older than their female counterparts (41.74 vs. 40.39). However, the difference between the means obtained from $\mathrm{T}$ test analyses was not significant. The men had a significantly higher level of work experience than the women (19.89 years vs. 17.61 years). Nevertheless, both men and women had the same level of seniority within the organization (12.1 years vs. 12.1 years) and in their present jobs (1.7 years vs. 1.7 years). In terms of education, more men than women had postgraduate qualifications (Master's degree) (25\% vs. 16.9\%). However, more male managers had not obtained a college studies diploma (30.2\% vs. $22.0 \%)$. A significantly higher number of female managers worked in the public sector $(87.6 \%$ vs. $67 \%)$ and held line positions (64.8\% vs. 55.3\%). However, the percentage of married men was much higher than the percentage of married women $(90.8 \%$ vs. $58.9 \%)$, 
and the average number of dependents was higher for men than for women (2.6 vs. 0.6). On average the male managers worked more hours per week than their female counterparts (41.5 vs. 37.2). There were no significant differences for the other variables shown in Table 1 (budget, supervision).

\section{Insert table 1}

\section{Dependent Variables}

Career advancement was defined using the following four variables: salary, hierarchical level, number of promotions and speed of promotion. These four variables were therefore the dependent variables in the study.

Salary: Salary was divided into $\$ 5,000$ segments as shown below.

$\begin{array}{llll}1) & \text { Less than } \$ 15,000 & 7) & \$ 40,000-\$ 44,999 \\ 2) & \$ 15,000-\$ 19,999 & 8) & \$ 45,000-\$ 49,999 \\ 3) & \$ 20,000-\$ 24,999 & 9) & \$ 50,000-\$ 54,999 \\ 4) & \$ 25,000-\$ 29,999 & 10) & \$ 55,000-\$ 59,999 \\ 5) & \$ 30,000-\$ 34,999 & 11) & \$ 60,000 \text { or more } \\ 6) & \$ 35,000-\$ 39,999 & & \end{array}$

Hierarchical level: The hierarchical level of respondents was identified using a scale from A (senior management level) to $\mathrm{G}$ (foreman level). A decreasing numerical value was assigned, 7 for level $A$ and 1 for level $G$.

Level A:SENIOR MANAGEMENT LEVEL, I.E. THE PRESIDENT, THE CEO AND THE CEO'S CLOSE COLLEAGUES FORMING THE MANAGEMENT TEAM.

Level B: Closer to Level A than to Level D.

Level C: Closer to Level D than to Level A.

Level D:HALFWAY BETWEEN SENIOR MANAGEMENT AND THE LOWEST SUPERVISORY LEVEL.

Level E: Closer to Level D than to Level G.

Level F: Closer to Level G than to Level D.

Level G:THE LOWEST SUPERVISORY LEVEL, I.E. THE FOREMEN AND SUPERVISORY STAFF CLOSEST TO OPERATIONAL LEVEL. 
For the purposes of interpreting the results, we grouped the different hierarchical levels into three categories: Category 1 (Levels F and G), Category 2 (Levels C, $\mathrm{D}$ and $\mathrm{E}$ ) and Category 3 (Levels $\mathrm{A}$ and B).

Number of promotions within the organization: To obtain the number of promotions within the organization, we used the following question: Since you work for this organization, how many promotions did you received?

Seniority : Number of years of service for your current employer:

Speed of promotion: The speed of promotion was obtained by calculating the quotient of the number of promotions within the organization and seniority within the organization.

\section{Independent Variables}

The set of control variables includes five distinct variables: age of respondents, number of years of experience in the workforce, number of years of seniority in the organization, number of years of seniority in the current position and the employment track ("Staff"= 1, "Line" = 2).

Human capital was measured using two separate variables, i.e. level of education according to qualifications obtained (elementary $=1$; secondary $=2$; vocational secondary $=3$; college $=4$; undergraduate degree $=5$; Master's degree $=6$; Ph.D.=7) and the number of changes of employer during the career.

Family context was measured using three variables including: family situation, represented by two possibilities ("living alone" or "married") and number of dependents, represented by the number of people financially dependent on the respondent.

Socioeconomic origin was measured using five variables representing the father's profession: farmer, non-specialized laborer, office worker, executive/professional and entrepreneur. The variable representing the father's 
profession was coded 1 , and all the others were coded 0 .

The values and motivations of respondents were measured using three groups of variables, including organizational commitment, measured in two ways (number of hours worked in a typical week, and number of overtime hours that respondents were willing to work in exchange for a $20 \%$ salary increase) and perception of instrumental "performance/reward" link, constructed using four statements (alpha $=0.63)$ and accompanied by a four-point Likert scale ranging from "will not happen" to "will happen".

The structural variables included sector (private sector $=1$, public sector $=2$ ), and administrative and budgetary responsibilities, measured using the following two questions: "Are you responsible for an administrative unit?" and "If yes, what is the approximate budget of the administrative unit for which you are responsible?". Respondents were also asked to indicate the number of people reporting directly to them.

\section{Analysis}

We began by conducting variance (T-test) and homogeneity (Chi-square) analyses to verify the existence of a male-female career success differential in our sample. This was followed by a correlation analysis aimed at detecting the presence of multicollinearity. According to Nie et al. (1975), if two variables are to be treated independently, their collinearity should not exceed 0.8 .

Subsequently, to assess the impact of each group of variables on career advancement, we opted for a hierarchical regression analysis. At the beginning of each analysis we included a group of variables to control, as far as possible, the factors having a potential impact on the career success of managers. Factors such as labor market experience, seniority within the organization, seniority in the job and position held (staff or line) can influence the career advancement of individuals. By introducing this group of control variables at the beginning of the regression analysis, we were better able to identify the respective influence of each variable block analyzed. The variable blocks (human capital, family context, socioeconomic origin, values and motivation, structural variables) were entered individually for each of the dependent variables (salary, hierarchical level, number of promotions, speed of promotion). The "gender" variable was then added after each variable block, to see whether or not gender continued to 
influence career advancement. In other words, we first introduced the control variable block, then the independent variable block, and finally gender. Consequently, if gender increased the explanatory value of the variable block in question, then that block was not sufficiently powerful to explain all the difference in the level of career success achieved by male and female managers.

Finally, two overall regression analyses containing all the variables from the model were conducted in using the "Enter" algorithm. One form of analysis verified whether the variables selected had a distinctive influence on the careers of males and females, and the other was designed to observe whether the "gender" variable explained a significant portion of the variance in career success when all other variables were controlled. In addition, the two analyses were intended to provide additional support for our seventh hypothesis, and to feed the discussion.

\section{Results}

The female managers in our sample, despite the fact that age and level of seniority within the organization were similar to those of their male counterparts, achieved lower levels of career success for all four success variables (salary, hierarchical level, number of promotions, speed of promotion). More than $25 \%$ of the male managers earned more than $\$ 40,000$ per year, compared with only $6 \%$ of the female managers. A similar situation was observed for hierarchical level and the number and speed of promotions. Twice as many men held senior positions in the hierarchy (33.1\% vs. $16.9 \%)$. The men had also received more promotions on average since joining the organization (3.69 vs. 2.22) and obtained faster promotion than the women ( 0.20 vs. 0.14$)$, which supports our first hypothesis. The Student $\mathrm{T}$ and Chi-square analyses showed that all the observed differences were significant $(\mathrm{p}<=0.001)$.

The correlation analysis shown in Table 2 revealed the presence of collinearity between the "Age" and "Work experience" variables ( $0.83 * * *)$. Consequently, we eliminated age and retained work experience in our regression analyses, since work experience was more consistent with the concerns of the research. As regards the other relationships, no collinearity was detected, suggesting that all the variables can be treated as independent.

Insert Table 2 
The regression analyses in Table 3 show the influence of the control variables on career success among managers. This first group of variables explains in large part the variance in number of promotions $\left(\mathrm{R}^{2}=18.9 \%\right)$. However, this group of variables had a less significant impact on speed of promotion $\left(R^{2}=9.7 \%\right)$, salary $\left(\mathrm{R}^{2}=7.0 \%\right)$ and hierarchical level $\left(\mathrm{R}^{2}=2.5 \%\right)$.

Insert Table 3

When the "gender" variable was added to the model, the explanatory percentage of all the variables studied increased. The percentage increase in the explained variation was greatest for salary $\left(\mathrm{R}^{2}=5.7 \%\right)$, and ranged from $2.3 \%$ to $2.9 \%$ for the other variables. The Fischer's $F$ value suggests that the difference observed following the addition of the "gender" variable is significant for all the aspects of success used in the study. The Beta for the gender variable was negative and significant for all aspects of career success. The greatest value was obtained for salary $(\beta=-0.25 ; \mathrm{p}<=0.001)$, while the values for all other aspects of success were similar $(B=-0.16 ; p<=0.001)$. These results suggest that the "work experience" variable block does not fully explain the different levels of career success achieved by male and female managers, and that men are, to some extent, at an advantage in career terms or, the opposite, women are at a disadvantage in career terms.

When the effects of the diverse variables comprising this first block are observed individually, it becomes apparent that the variables have a distinctive influence on males and females (Table 4). For example, males use their work experience to gain salary increases $\left(\beta=0.30^{* * *}\right)$, whereas work experience for women has a more significant influence on the number $\left(\beta=0.22^{*}\right)$ and speed $\left(\beta=0.26^{* *}\right)$ of promotions. The results also reveal that it would be preferable for female managers to achieve success early in their careers, as their seniority in the organization and in the position has a negative effect on their speed of promotion $\left(\beta=-0.23^{* *}, \beta=-0.39^{* * *}\right)$. This trend was much less evident in male managers. Moreover, the number of years in the same position has a greater negative influence on the number of promotions for women $\left(\beta=-0.39^{* * * *}\right)$ than for men $\left(\beta=-0.20^{* * *}\right)$. Lastly, it is to managers' advantage to avoid Staff positions if they aspire toward high salaries and climbing the hierarchy ( $\beta=$ $\left.0.10^{* *}, \beta=-0.13^{* * *}\right)$. Nonetheless, in terms of hierarchical level, only women are penalized for holding a Staff position. 
Insert Table 4

\section{Human capital}

The group of variables linked to human capital significantly increases the level of variance explained by salary $\left(\mathrm{R}^{2}=33.7 \% ; \mathrm{F}=136.78^{* * *}\right)$ and hierarchical level $\left(\mathrm{R}^{2}=9.4 \% ; \mathrm{F}=26.57\right)$, but does not affect the number and speed of promotions (Table 5). A higher level of human capital therefore does not necessarily entail more promotions, although it has a positive influence on hierarchical advancement and salary.

Insert Table 5

The addition of the "gender" variable significantly increased the $\mathrm{R}^{2}$ values for all career success factors (Table 5). Again, the gender of respondents had the most impact on salary $\left(\mathrm{R}^{2}=6.1 \%\right)$, and its value for the other elements ranged between $2.6 \%$ for hierarchical level, $2.3 \%$ for number of promotions and $2 \%$ for speed of promotion. The Fischer's F value suggests that the observed $\mathrm{R}^{2}$ variations are all significant $(\mathrm{p}<=0.001)$. Our second hypothesis is therefore not confirmed, because the human capital variable group does not fully explain the differential in the levels of career success observed and does not eliminate the influence of the "gender" variable. The negative Beta values suggest that male managers have an advantage over their female counterparts. These values are similar to those observed above, and suggest that the negative effect is largest in relation to salary $\left(\beta=-0.25^{* * *}\right)$.

The results shown in Table 4 suggest that the level of education influences the hierarchical level among male managers $(\beta=0.20 * *)$ but not among female managers. However, this variable influences salary among men and women alike. In addition, the level of education is by far the most important variable in the wage model, especially among women. Regarding the number of employers, one can note that external mobility (lack of loyalty toward the organization) is penalized considerably more in female managers than in male managers. In effect, female managers tend to earn fewer promotions $\left(\beta=-0.23^{* *}\right)$ and experience a lower promotion speed $(\beta=-0.29 * *)$ when they change employers frequently. Among male managers, salary is the only variable negatively affected 
by a lack of loyalty $\left(\beta=-0.13^{* *}\right)$.

\section{Family context}

The set of variables linked to family context did not have a major impact on managers' career success. As seen in Table 6 , only salary $\left(\mathrm{R}^{2}=2.2 \%, \mathrm{~F}=4.16^{* *}\right)$ and the number of promotions $\left(\mathrm{R}^{2}=1.5 \%, \mathrm{~F}=3.06^{* *}\right)$ are affected by the managers' family context.

Insert Table 6

Again, the "gender" variable produced an effect on all aspects of career success, thus invalidating our third hypothesis. Consequently, we can state that family context does not explain variations in the levels of success achieved. The impact of gender was particularly significant for salary $\left(R^{2}=3.1 \% ; F=18.5 ; \mathrm{p}<=0.001\right)$ and hierarchical level $\left(\mathrm{R}^{2}=2.4 \% ; \mathrm{F}=12.8 ; \mathrm{p}<=0.001\right)$ and, to a lesser extent, the number of promotions $\left(\mathrm{R}^{2}=1.6 \% ; \mathrm{F}=10.1 ; \mathrm{p}<=0.01\right)$ and speed of promotion $\left(\mathrm{R}^{2}=1.7 \% ; \mathrm{F}=9.9^{* *} ; \mathrm{p}<=0.01\right)$. The negative Beta values observed in Table 6 once again suggest that men are at a advantage in comparison to their female counterparts.

The results in Table 4 indicate that among male managers, career success alone is influenced by marital status. In other words, marriage tends to have a negative effect on males' salaries $\left(B=-0.16^{* *}\right)$ only. Nonetheless, the level of family responsibilities has a positive influence on managers' salaries, regardless of gender. The more children the managers have, the higher their salaries tend to be.

\section{Socioeconomic Origin}

The socioeconomic origin model explained some of the variance observed, but only for salary $\left(\mathrm{R}^{2}=4.3 \% ; \mathrm{F}=3.6 ; \mathrm{p}<=0.001\right)$. However, none of the variables used in the model was found to be significant. Socioeconomic origin is therefore not a very good determinant of career success.

Insert Table 7 
Gender, introduced as a final group of variables after the control variables and the socioeconomic origin group, increased the level of explained variation quite significantly. The $\mathrm{R}^{2}$ value increased significantly for salary $\left(\mathrm{R}^{2}=5.6 \% ; \mathrm{F}=34.8\right.$; $\mathrm{p}<=0.001)$, hierarchical level $\left(\mathrm{R}^{2}=2.5 \% ; \mathrm{F}=13.9 ; \mathrm{p}<=0.001\right)$, number of promotions $\left(\mathrm{R}^{2}=2.7 \% ; \mathrm{F}=17.8 ; \mathrm{p}<=0.001\right)$ and speed of promotion $\left(\mathrm{R}^{2}=2.3 \%\right.$; $\mathrm{F}=13.6 ; \mathrm{p}<=0.001)$. Our fourth hypothesis is therefore not confirmed, because the socioeconomic origin of the managers in our sample did not fully explain the different levels of success obtained by men and women. Moreover, the Beta values of the "gender" variable were negative for all four aspects of career success.

\section{Individual values and motivations}

With the exception of hierarchical level, the set of variables linked to individual values and motivations has a considerable influence on the career success of managers. Table 8 reveals a variation in variance explained from $8.2 \%$ for salary, to $5.1 \%$ for the number of promotions and $5.4 \%$ for promotion speed. The $\mathrm{F}$ values are significant $(\mathrm{p}<=0.001)$ for the three variables in question. Therefore, individual values and motivations have no significant impact on the hierarchical level of the managers in our sample.

Insert Table 8

The addition of gender to this latter group of variables significantly increased the level of explained variation for salary $\left(\mathrm{R}^{2}=4.3 \% ; \mathrm{F}=25.1 ; \mathrm{p}<=0.001\right)$, hierarchical level $\left(\mathrm{R}^{2}=1.4 \% ; \mathrm{F}=6.9 ; \mathrm{p}<=0.01\right)$ and number of promotions $\left(\mathrm{R}^{2}=0.9 \% ; \mathrm{F}=5.6\right.$; $\mathrm{p}<=0.05)$. However, gender did not increase the weight of the model with respect to speed of promotion. Our fifth hypothesis is therefore partially confirmed, because individual values and motivations attenuate the influence of gender, but only for speed of promotion. The Beta value is negative and significant between gender and all the dependent variables, showing once again the favorable situation of the male managers in our sample.

Table 4 clearly illustrates the influence of the variables used in this model. Work investment, represented by the number of work hours per week, is the most important variable. It has a positive and significant influence on three of the four dimensions of success (i.e. salary, number of promotions and promotion speed). The most committed managers are thus more successful. However, this 
investment has a more significant influence among men than among women. In effect, the number of hours worked per week has a positive impact on the number and speed of promotions among male managers only $\left(\beta=0.20^{* *}\right)$. Nonetheless, only female managers' salaries are influenced favorably by the number of hours worked $\left(\beta=0.18^{* * *}\right)$. The perception of an instrumental link is the second significant variable in this model. However, its influence was seen uniquely in the hierarchical level of female managers $(\beta=0.25 * *)$.

\section{Structural model}

The last model used - the structural model - also explained a significant percentage of the variation in managerial career success. In fact, it was the most powerful model after human capital, increasing the percentage of explained variation by more than $26.3 \%$ for salary, $11.9 \%$ for hierarchical level, $3.6 \%$ for number of promotions and $2.8 \%$ for speed of promotion (Table 9). The $\mathrm{R}^{2}$ values for all these variations were significant $(\mathrm{p}<=0.001)$.

Insert Table 9

When gender was added to the model, it explained $8.8 \%$ of the variation for salary, $3.5 \%$ for hierarchical level, $1.7 \%$ for number of promotions and $1.1 \%$ for speed of promotion. All observed variations were significant. Since gender is a significant variable in this model, we can conclude that the structural model alone does not explain the different levels of career success obtained by men and women. Consequently, our sixth hypothesis is not confirmed. The Beta values between gender and career success are once again negative and significant, placing the women at a disadvantage.

The sector of activity and budget size managed are the most important variables in this model (Table 4). Our results suggest that male managers working in the public sector tend to earn the highest salaries $\left(\beta=0.26^{* * *}\right)$. This is not the case for female managers. In contrast, the public sector has a positive effect on the hierarchical level of women exclusively $\left(\beta=0.27^{* * *}\right)$. Consequently, the number and speed of promotions does not seem to be affected by the sector of activity. Furthermore, the budget managed has a greater influence on the salaries of males than females ( $\beta=0.30^{* * *}$ vs. $\left.\beta=0.18^{* *}\right)$. In fact, the budget influences the hierarchical level of men only $\left(\beta=0.19^{* * *}\right)$. Lastly, administrative responsibilities seem to have a much greater influence on career success among 
men, as do supervision responsibilities among women. In effect, male managers reach a higher hierarchical level when they have administrative responsibilities $\left(\beta=0.15^{*}\right)$, whereas among female managers, the hierarchical level and number of promotions that they earn are influenced considerably by the number of persons under their supervision $(\beta=0.18 * * ; \beta=0.20 * *)$

Overall, these results show that the different variable blocks used (human capital, family context, socioeconomic origin, values and motivations, sector-based and organizational environment) do not for the most part counter the significant impact of gender on the career success of the managers in our sample. With the exception of speed of promotion in the "values and motivations" model, the results show that none of the models used explains enough of the variation to eliminate the effect of gender. In addition, all the regression coefficients between gender and the various aspects of career success are negatives, thus confirming our seventh hypothesis, that the presence of discrimination cannot be eliminated.

Finally, even when all the variable blocks were used in a single regression model (Table 10), the "gender" variable (step 7) continued to have a significant impact on two aspects of career success: salary $\left(\mathrm{R}^{2}=3.1 \% ; \mathrm{F}=29.9 ; \mathrm{p}<=0.001\right)$ and hierarchical level $(\mathrm{R} 2=2.0 \% ; \mathrm{F}=9.2 ; \mathrm{p}<=0.01)$. These results suggest that female managers are not penalized in terms of the number of promotions and speed of promotion, but are penalized significantly in terms of salary $(\beta=-0.24 ; \mathrm{p}<=0.001)$ and hierarchical level $(\beta=-0.21 ; \mathrm{p}<=0.001)$.

Insert Table 10

\section{Discussion}

The goal of this research was to test whether male-female variations in managerial career success could be explained through five separate theoretical approaches currently used in research: human capital, family context, socioeconomic origin, values and motivations, and sector-based and organizational factors.

The results supported only our first and last hypotheses, and hypotheses $2,3,4$, 5 and 6 , representing the five approaches, were not confirmed. Taken individually, these different approaches did not counter the effect of gender on 
the career success of managers. Only the "values and motivations" variable block eliminated the effect of gender, and even then, only for speed of promotion. The use of an overall regression model containing all the approaches countered the effect of gender on the number of promotions and speed of promotion, but gender continued to have a major effect on salary and hierarchical level. It is therefore possible that female managers receive promotions with a purely symbolic value. They do not appear to be assigned to high-profile, challenging jobs, thus considerably reducing their chances of obtaining well-paid senior positions (Ohlott et al., 1994).

The confirmation of our first hypothesis supports most previous work, to the effect that there is a significant male-female differential in objective managerial career success (Stroh et al., 1992; Cannings, 1991, 1988; Eberts and Dipboye, 1987). Although men and women now have equal chances of obtaining a managerial position (Shenhav, 1992) and the men and women in our sample had the same number of years of seniority within the organization and in their current job, women still take longer to achieve comparable levels of success.

As the results show, the human capital variables explain a significant percentage of managerial career success. Even though this group explains nearly $34 \%$ of the observed variation in salary and $10 \%$ in hierarchical level, human capital as we measured it did not counter the effect of gender on career success. In fact, the significant change in $\mathrm{R}^{2}$ values and the significant negative Standardized Beta values obtained suggest that gender continues to explain a large percentage of success, and works against the interests of female managers. Our results do not support the argument that women invest less in their training and experience and thus achieve less success than men. The longitudinal study by Neumark and Mclennam (1994) challenges the causal link between the investment made by women in their careers and the poor results obtained, suggesting instead that the lack of career success obtained incites women to invest less than their male counterparts in their careers. To reduce the effects of discrimination, women often tend to invest considerably more in the family sphere, or to change employers. Our results suggest that this frequent change of employer is significantly more harmful to career success among female managers than among male managers.

In addition, the seniority of the female managers in the organization and the position, in contrast with their male counterparts, has a strong and negative impact on women's promotion speed. The female managers must therefore succeed from the start of their careers, because as time passes, the slimmer their changes become. Their possible withdrawal from the workforce to respond to 
family demands acts as a clock that urges them to succeed before the critical time. Consequently, as this deadline approaches, the less likely organizations are to support career advancement in women. Moreover, work experience alone has a positive impact on males' salaries. The possibility that women are absent more often from the workforce thus reduces the value that organizations are prepared to grant their work experience. According to Rosenbaum's (1979) tournament theory, individuals who do not follow their cohort (e.g. women), must compete between themselves for less important positions, thus reducing their chances of reaching the summit.

Our results also show that family context does not have a major effect on the career success of managers. Differences in career success observed between males and females are therefore not attributable to family context. The fact of living alone or with a spouse does not seem to influence the level of success obtained. Contrary to the findings of Lee and Kanungo (1984), people living alone do not necessarily invest more in their careers to make up for the lack of established social structure outside their work. Moreover, contrary to Kanter (1977) theory and the findings of Pfeffer and Ross (1982), the spouses of married managers are definitely not considered to be resource people who allow their partners to invest more in their careers. The other significant variable in the model is the number of dependents, which has a positive impact on salary. Nevertheless, the family context does not seem to explain the observed variation in career success. The financial situation of female managers since the $1980 \mathrm{~s}$ probably enables them to employ outside help, thus reducing the negative impact of family responsibilities on their success (Kichmeyer, 1993).

Socioeconomic origin does not explain career success. Despite a significant $\mathrm{R}^{2}$ variation for salary, none of the variables used in the model led to interesting conclusions. Contrary to the findings of other authors (Orstein, 1983; Cohen, 1986; Whitely et al., 1991), the professional status of the father does not seem to influence the career advancement of the children. When socioeconomic origin is taken into account, male and female managers do not obtain the same level of career success. It is therefore no longer a major determinant, and individuals now have more influence on their own destinies.

The individual values and motivations of managers play an important role in their success. The level of variation explained by this model is considerably higher than the figure obtained in previous studies (Tharenou and Conroy, 1994; Jaskolka et al., 1985). The number of hours worked per week was found to be the most important variable in the model, confirming the findings of Judge and Bretz (1991). Managers are thus rewarded for the effort they devote to their work. The 
people with high levels of work investment are those who focus most on the positive elements of their environment, and who are used to interpreting events as favorably as possible (Lee et al., 1992). Organizations thus tend to offer the best career opportunities to the most committed people, increasing their chances of success (Aryee et al., 1994). Nonetheless, this recognition by the organization takes different forms for men and women. Our results suggest that female managers are rewarded by salary, whereas male managers are compensated more along promotional lines. It is true that the link between the number of hours worked and the promotions earned is much more subjective than that between the number of hours worked and the salary, particularly in the public sector, where most of the female managers in our sample was concentrated. Consequently, to avoid discrimination, it is possible that organizations reward overtime financially in women, while offering promotions to the most committed male managers.

The perception of the instrumental link (performance/reward) was found to be the only other significant variable in the model and on women hierarchical level only. Therefore, women require a broader perception of fairness to be motivated and to exert the effort required for successful performance. As the level of performance is strongly linked to career success (Gehart, 1990), it is therefore probable that women who perceive a stronger instrumental link are also those who have the greatest opportunities for promotion. Nonetheless, the differences observed in men and women in terms of values and motivations do not negate the significant influence of gender on salary, the hierarchical level and the number of promotions. Other factors must therefore underlie the gap in career success observed.

Finally, our results also show that a large part of managerial career success is explained by the sector (public/private) and by certain organizational factors. In this respect, managers wishing to obtain better salaries and jobs further up the hierarchical ladder should consider moving into the public sector, which has a positive effect on these two aspects of career success. According to Ornstein (1983), the return on experience and education tends to be better in the public sector, which would explain our results. Contrary to the findings of Almquist (1987), the public sector is not more favorable to women than to men. Male and female managers simply do not benefit in the same way from their employment in the public sector. Male managers tend to earn higher salaries in the public sector whereas female managers tend to hold higher hierarchical positions. The rules and legislation that govern the public sector thus enable women to benefit from better promotion opportunities without reaping the salary advantages. The reason for this is that regardless of the sector of activities, men nonetheless hold higher hierarchical positions, where the best salaries are offered (Steinberg et al., 
1990).

Furthermore, our results suggest that companies confer higher salaries and hierarchical positions on managers who have the greatest budgetary and administrative responsibilities. This finding corroborates that of Hersch (1991) and Cannings (1988A). In effect, the scope of the decision-making and financial latitude of managers who hold positions with high levels of responsibility can have a major impact on the future of the company. Consequently, the company is forced to offer privileged work conditions. However, the responsibilities assumed by managers seem to be recognized considerably more in males than in females. Admittedly, our sample contained twice as many men as women, in senior positions. Indeed, it is the men who occupy these senior positions who are responsible for the creation and control over consequential policies and practices. This context represents a potential obstacle in the recognition of responsibilities assumed by female managers. Nonetheless, our results show that for female managers, only career success is influenced by the number of people supervised. It is possible that once a manager exceeds a certain hierarchical level, his or her type of responsibility and role of may change. Thus, male managers may delegate their supervisory responsibilities to female managers at a lower hierarchical level, to focus on the financial, strategic and political aspects of the company (Steers and Ungson, 1987).

Contrary to several studies which suggested that the sector may be responsible for differences in the salaries paid to men and women, our results are very clear and show that gender continues to have a major and significant impact on career success, even after controlling sector and organizational factors. Consequently, the concentration of female managers in the public sector and the lower level of responsibility inherent in the positions occupied by women do not fully explain the lack of career success achieved by women.

The use of an overall regression model (Table 10) did not enable us to eliminate the influence of gender on career success. In fact, after having controlled labor market experience, human capital, family context, socioeconomic origin, values and motivations, sector and organizational factors, the gender of respondents continued to explain a significant percentage of the variation in salary and hierarchical level. However, after the variables were controlled, the number of promotions and speed of promotion did not seem to depend on gender. Female managers thus seem to have the same chance as male managers of obtaining promotion and being promoted within the same time frame, but have less chance of obtaining the same salary and hierarchical level. This suggests that the promotions obtained by women do not necessarily have the same meaning as 
those obtained by men.

The source of the remaining discrimination is more difficult to explain. Although more than $61 \%$ of the salary variation was explained by our findings, a nonnegligible portion (39\%) was not. This was even more striking in the case of hierarchical level. To what can this unexplained variation be attributed? Can we conclude beyond all doubt that discrimination still exists?

Despite the large number of variables used in this study, some aspects that may have an impact on career success should be considered in future research. For example, it may well be that the different levels of career success are explained by the different career development opportunities available to men and women (Ohlott et al., 1994). Women may face career development obstacles unrelated to their jobs. One of these may be lack of support from colleagues and superiors. Tharenou et al. (1994) identified training and individual development within an organization as a latent variable that seems to influence career advancement, and through which the influence of a major set of variables is filtered (e.g. work experience, self-confidence, family context, etc.). This aspect of career success would thus be central to the model.

Similarly, the mentoring process may be experienced differently by men and by women. The large percentage of male mentors means that relationships are established between men and women, creating a context of social ambiguity. In this respect, Kirchmeyer (1996) showed that mentoring has a significant effect on the salaries of men only.

The differing ability of men and women to use political tactics (e.g. informal networks) may also be a major element. Judge and Bretz (1994) showed that this aspect had a significant impact on individual career success. Women do not receive support from their colleagues, and are consequently kept out of the influential networks in which political strategies are decided (Ohlott et al., 1994).

Finally, our samples of men and women were not completely homogeneous. Despite similar ages and levels of organizational and job seniority, the male and female managers in our study did not have the same type of educational qualifications or work experience outside the organization.

\section{Conclusion and Organizational Consequences}

Our findings do not enable us to eliminate the possibility of discrimination by Canadian's enterprises. Despite the fact that we used an almost homogeneous sample and controlled a large number of variables related to different theoretical 
and conceptual approaches, gender nevertheless continued to have a significant impact on the salary and hierarchical level of the managers studied. The approaches used therefore did not fully explain the male-female differential in the levels of career success observed. In addition, it was possible to observe that career success among men and women was not influenced by the same variables. In effect, female managers were best served by succeeding at the start of their careers, and by taking on considerably more supervisory responsibilities and remaining at the same company as long as possible. Among male managers, work experience, commitment to the organization and administrative and budgetary responsibilities were highly rewarded by the company. Note that these results do not represent a cure-all but rather a trend observed in a given sample.

In terms of organizational consequences, the male-female career success differential shows that enterprises perhaps do not always invest in their most competent and promising employees. In fact, many of them seem to forget the difficult context of market globalization and the extreme competition it generates. To beat their foreign competitors, North American firms must rely on a highly competent workforce. Consequently, they must make the most of their best resources, whether male or female. They should also help their employees to reconcile work and family commitments, thus retaining their most promising elements of both sexes. Competent female managers who do not feel they are receiving fair and equitable feedback in terms of career success will be the first to change employers, and this will obviously affect the performance of the enterprise. 


\section{References}

Abbott, P. (1990), "A Re-examination of Three Theses Re-examined", in Payne, G. and Abbott, P. (ed.), The Social Mobility of Women: Beyond Male Mobility Models, The Falmer Press, 37-45.

Acker, A. (1990), "Hierarchies, Jobs, Bodies: A theory of Gender Organizations", Gender \& Society, 4, 2, June, 139-158.

Almquist, E.M. (1987), "Labor Market Gender Inequality in Minority Groups", Gender \& Society, 1, 4, December, 400-414.

Aryee, S. ; Chay, Y.W. ; Tan H. H. (1994), «An Examination of the Antecedents of Subjective Career Success Among a Managerial Sample in Singapore», Human Relations, 47, 5, 487-50.

Becker, G.S. (1975), Human Capital, Chicago: University of Chicago Press.

Blum, T.C. ; Fields, D.L. ; Goodman, J.S. (1994,) «Organization-Level Determinants of Women in Management», Academy of Management Journal, 37, 2, 241-288.

Cannings, K. (1988 A), "The Earnings of Female and Male Middle Managers", Journal of Human Resources, 23, Winter, 34-56.

Cannings, K. (1991), "An Interdisciplinary Approach to Analyzing the Managerial Gender Gap", Human Relations, 44, 7, 679-695.

Cannings, K. (1988 B), "Managerial Promotion: The Effects of Socialization, Specialization, and Gender", Industrial and Labor Relations Review, $42,1,77-88$.

Chapman, T. (1990), "The Career Mobility of Women and Men", in Payne, G. and Abbott, P. (ed.), The Social Mobility of Women: Beyond Male Mobility Models, The Falmer Press, 73-81.

Cohen, Y. (1986), "Family Background and Economic Success Through Work and Marriage", Research in Social Stratification and Mobility, 5, 173197.

Crompton, R. and Sanderson, K. (1990), "Credentials and Careers", in Payne, G. and Abbott, P. (ed.), The Social Mobility of Women: Beyond Male Mobility Models, The Falmer Press, 83-100.

Derr, C.B. and Laurent, A. (1989), "The Internal and External Career: a Theoretical and Cross-Cultural Perspective", The Handbook of Career 
Theory, in Arthur, M.B., Hall, D.T. and Lawrence, B.S., Cambridge University Press, 454-471.

Derr, C.B. (1986), Managing the New Careerists, Jossey-Bass Inc., Publishers, San Francisco, California.

Dipboye, R.L. (1987), "Problems and Progress of Women in Management". In K.S. Koziara, M.S. Moskow, and L.D. Tanner (Eds.), Working Women: Past, Present, and Future, Washington, DC: BNA Books, 118-153.

Eberts, R.W. and Stone, J.A. (1985), "Male-Female Differences in Promotions: EEO in Public Education", The Journal of Human Resources, 20, 4, 504-521.

Featherman, D.L. and Hauser, R.M. (1976), "Sexual Inequalities and Socioeconomic Achievement in the U.S. 1962-1973", American Sociological Review, 1976, 41, June, 462-483.

Gattiker, U.E. and Larwood, L. (1990), "Predictors for Career Achievement in the Corporate Hierarchy", Human Relations, 43, 8, 703-726.

Gerhart, B. (1990), «Gender Differences in Current and Starting Salaries : the Role of Performance, College Major, and Job Title», Industrial and Labor Relations Review, 43, 4, 418-433.

Groshen, E.L. (1990), "The Structure of the Female/Male Wage Differential. Is It Who You Are, What You Do, or Where You Work?", The Journal of Human Resources, XXVI, 3, 457-472.

Hannan, M.T., Schömann, K. and Blossfeld, H-P. (1990), "Sex and Sector Differences in the Dynamics of Wage Growth in the Federal Republic of Germany", American Sociological Review, 55, October, 694-713.

Hersch, J. (1991), "Male-Female Differences in Hourly Wages: The Role of Human Capital, Working Conditions, and Housework", Industrial and Labor Relations Review, 44, 4, July, 746-759.

Jacobs.J.A., (1992), «Women's entry into management: Trends in earnings, authority, and values among salaried managers», Administrative Science Quarterly, 37: 282-301.

Jaskolka, G., Beyer, J.M. and Trice, H.M. (1985), "Measuring and Predicting Managerial Success", Journal of Vocational Behavior, 26, 189-205.

Johnsrud, L.K. (1991), "Administrative Promotion: The Power of Gender", Journal of Higher Education, 62, 2, March/April, 119-149. 
Judge, T.A. ; Bretz, Jr, R.D. (1994), « Political Influence Behavior and Career Success», Journal of Management, 20, 1, 43-65.

Kanter, R.M. (1977), Men and Women of the Corporation, Basic Books, inc., Publisher, 303.

Kirchmeyer, C. (1993), «Nonwork-to-work splillover : A more balanced view of the experiences and coping of professional women and men», Sex Roles, 28, pp. 531-552.

Kirchmeyer, C. (1996), «Determinants of Managerial Career Success : Firm Evidence and Explanation of Male/Female Differences», Paper presented at the 1996 annual meeting of the Academy of Management, Cincinnati.

Konrad, A.M and Cannings, K. (1991), "The Mommy Track and the Glass Ceiling in Canada, the U.S. and Western Europe", Managing in a Global Economy IV, Proceedings of the Fourth International Conference, Eastern Academy of Management, in McGuire, J.B., Yanouzas, J., Bernasconi, M. and Westacott, G. (ed.), Nice-Sophia, Antipolis, France, June, 19-23.

Lawler, E.E., III (1968), «A Causal Correlation Analysis of the Relationship Between Expectancy Attitudes and Job Performance», Journal of Applied Psychology, 52, 462-468.

Lee, M. and Kanungo, R. (1984), Management of Work and Personal Life: Problems and opportunities, in Lee, M. and Kanungo,R. (ed.), New York, Praeger Publishers, 1-9.

Lee, T.W., Ashford, S.J., Walsh, J.P. and Mowday, R.T. (1992), "Commitment Propensity, Organizational Commitment, and Voluntary Turnover: A Longitudinal Study of Organizational Entry Processes", Journal of Management, 18, 1, 15-32.

Lobel, S.A. ; St-Clair, L. (1992), «Effects of Family Responsibilities, Gender, and Career Identity Salience on Performance Outcomes», Academy of Management Journal, 35, 5, 1057-1069.

Medoff, J.L. and Abraham, K.G. (1980), "Experience, Performance, and Earnings", The Quarterly Journal of Economics, December, 703-736.

Neumark, D. ; McLennan, M. (1994),»Sex Discrimination and Women's Labor Market Outcomes», The Journal of Human Resources, 30, 4, 713-740. 
Nie, N.H., Hull, C.H., Jenkings, J.C., Brenner, K.S. \& Bent, D.H. (1975), Statistical Package for Social Sciences, McGraw-Hill Book co.

Ohlott, P.J. ; Ruderman, M.N. ; McCauley, C.D. (1994), «Gender Differences in Managers' Developmental Job Experiences», Academy of Management Journal, 37, 1, 46-67.

Ornstein, M.D. (1983), "Class, Gender, and Job Income in Canada", Research in Social Stratification and Mobility, in JAI Press Inc., 41-75.

Pfeffer, J. and Ross, J. (1982), "The Effects of Marriage and Working Wife on Occupational and Wage Development", Administrative Science Quarterly, 27, March, 68-80.

Pierce, J.L. and Dunham, R.B. (1987), "Organizational Commitment : PreEmployment Propensity and Initial Work Experiences", Journal of Management, 13, 1, 163-178.

Pigeon, G. (1988), "L'égalité des chances dans les entreprises . Le temps des solutions", Courants, février-mars, 22-26.

Rosenbaum, J.E. (1979), "Tournament Mobility : Career Patterns in a Corporation", Administrative Science Quarterly, 24, June, 220-241.

Schein, V.E., Mueller, R. and Jacobson, C. (1989), "The Relationship Between Sex Role Stereotypes and Requisite Management Characteristics Among College Students", Sex Roles, 20, 1/2, 103-110.

Shenhav, Y. (1992), "Entrance of Blacks and Women into Managerial Positions in Scientific and Engineering Occupations : a Longitudinal Analysis ", Academy of Management Journal, 35, 4, 889-901.

Steinberg, R.J., Haignere, L., and Chertos, C.H. (1990), "Managerial Promotions in the Public Sector. The Impact of Eligibility Requirements on Women and Minorities", Works and Occupations, 17, 3, 284-301.

Steers, R.M. and Rivera Ungson, G.R. (1987), "Strategic Issues in Executive Compensation Decisions", dans D.B. Balkin et L.R. Gomez-Mejia (eds), New Perspectives on Compensation, Prentice-Hall, 294-308.

Stewart, L.P and Gudykunst, W.B. (1982), "Differential Factors Influencing the Hierarchical Level and Number of Promotions of Males and Females Within an Organization", Academy of Management Journal, 25, 3, 586597. 
Stroh, L.K., Brett, J.M. and Reily, A.H. (1992), "All the Right Stuff: A Comparison of Female and Male Managers' Career Progression", Journal of Applied Psychology, 77, 3, 251-260.

Swimmer, G. (1990), "Gender Based Differences in Promotions of Clerical Workers", Relations Industrielles, 45, 2, 300-310.

Tharenou, P. ; Latimer, S. ; Conroy, D. (1994), «How do you Make it to the top? An Examination of Influences on Women's and Men's Managerial Advancement», Academy of Management Journal, 37, 4, 899-931.

Tharenou, P. ; Conroy, D. (1994), «Men and Women Managers’ Advancement: Personal or Situational Determinants», Applied Psychology : An International Review, 43, 1, 5-31.

Van Maanen, J. and Schein, E.H. (1977), "Career Development", in Hackman, J.R. and Suttle, J.L. (ed.), Improving Life at Work, Goodyear Publishing Company, Inc. 30-94.

Whitely, W., Dougherty, T.W. and Dreher, G.F. (1991),"Relationship of Career Mentoring and Socioeconomic Origin to Managers' and Professionals' Early Career Progress", Academy of Management Journal, 34, 2, 331 351. 
Table 1: Summary Characteristics of Sample

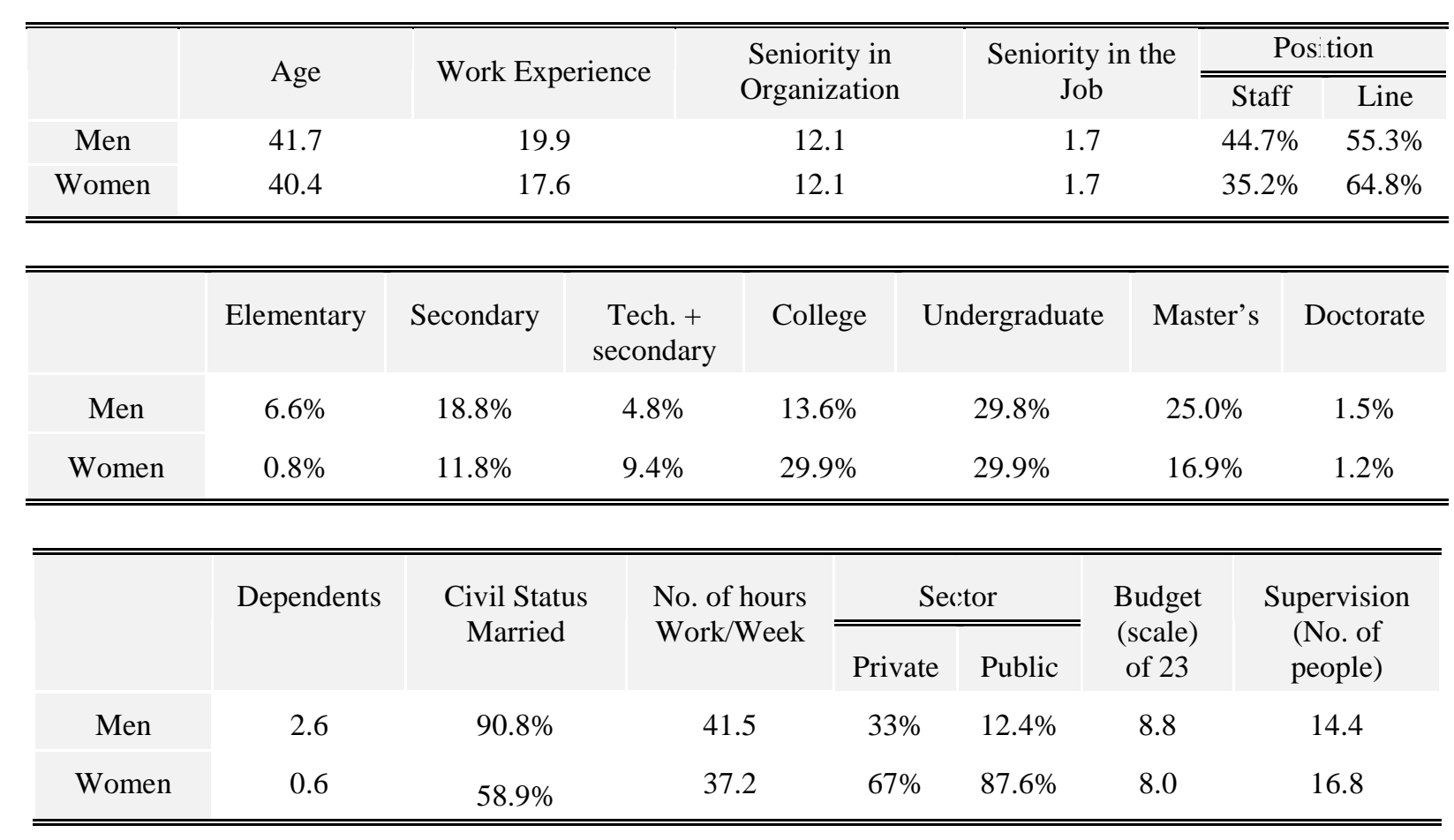




\section{Table 2: Correlation Table ${ }^{1}$}

\begin{tabular}{|c|c|c|c|c|c|c|c|c|c|c|c|c|}
\hline Variables & Mean & $\begin{array}{l}\text { Standard } \\
\text { Deviation }\end{array}$ & & & & & & & & & & \\
\hline & & & 1 & 2 & 3 & 4 & 5 & 6 & 7 & 8 & 9 & 10 \\
\hline 1 Age & 41.06 & 8.34 & 1 & & & & & & & & & \\
\hline 2 Seniority in organization & 12.06 & 4.81 & .37 & 1 & & & & & & & & \\
\hline 3 Seniority in job & 1.74 & .84 & .32 & .30 & 1 & & & & & & & \\
\hline 4 Labour market experience & 18.76 & 7.96 & .83 & .42 & .34 & 1 & & & & & & \\
\hline 5 Position (Staff/Line) & 1.60 & .49 & -.01 & -.02 & .02 & -.06 & 1 & & & & & \\
\hline 6 Level of Education & 4.27 & 1.49 & .08 & -.07 & -.16 & -.13 & .12 & 1 & & & & \\
\hline 7 Number of employers so far & 3.05 & 1.87 & .35 & -.19 & .00 & .32 & .00 & -.02 & 1 & & & \\
\hline 8 Married & .75 & .43 & .01 & .04 & .03 & .01 & .02 & -.02 & -.04 & 1 & & \\
\hline 9 Living alone & .14 & .34 & -.03 & -.02 & -.03 & .00 & .02 & .00 & .02 & -.69 & 1 & \\
\hline 10 Dependents & 1.61 & 1.57 & .04 & .08 & -.05 & .10 & -.05 & -.04 & .05 & .42 & -.37 & 1 \\
\hline 11 Farmer & .13 & .34 & .03 & .10 & .03 & .07 & -.09 & -.10 & -.05 & .02 & -.02 & .04 \\
\hline 12 Labourer & .27 & .44 & -.07 & .03 & .10 & -.02 & -.06 & -.13 & .01 & .05 & -.01 & .04 \\
\hline 13 Office worker & .06 & .24 & .02 & -.02 & -.08 & .03 & .02 & .07 & .02 & .03 & -.04 & .03 \\
\hline 14 Professional/Executive & .06 & .24 & -.01 & -.12 & -.02 & -.11 & .03 & .18 & .06 & .00 & -.04 & .02 \\
\hline 15 Entrepre & .18 & .38 & .11 & -.04 & -.01 & -.02 & .07 & .13 & .01 & -.08 & .07 & -.10 \\
\hline 16 Overt & 1.00 & 1.24 & -.06 & -.08 & -.01 & -.05 & .01 & -.06 & .05 & -.02 & .06 & .07 \\
\hline orked/week & 39.38 & 7.01 & .12 & .11 & -.07 & .15 & -.04 & .03 & .09 & .05 & -.05 & .23 \\
\hline 18 Link (pe & 8.55 & 2.63 & -.05 & .00 & -.06 & -.04 & -.10 & -.21 & .02 & .07 & -.04 & .18 \\
\hline 19 Sect & 1.77 & .4 & .13 & .03 & .09 & .00 & .22 & .52 & -.01 & -.09 & .04 & -.16 \\
\hline $20 \mathrm{~A}$ & 8.43 & 3.6 & .09 & .06 & -.08 & .07 & -.05 & .01 & .00 & .02 & .01 & .08 \\
\hline $21 \mathrm{R}$ & 1.30 & .46 & -.05 & -.08 & -.07 & -.06 & -.16 & -.16 & .03 & -.11 & .08 & -.15 \\
\hline people supervised & 15.57 & 18.16 & -.02 & .11 & -.01 & -.03 & .14 & .00 & -.05 & .08 & -.06 & .02 \\
\hline $23 \mathrm{Sa}$ & 5.46 & 1.92 & .30 & .03 & -.08 & .20 & .02 & .57 & .08 & .07 & -.05 & .18 \\
\hline $24 \mathrm{H}$ & & .77 & .17 & .03 & -.03 & .11 & -.06 & .29 & .04 & .01 & -.05 & .07 \\
\hline 25 Number of promotions & 1.92 & 1.49 & .00 & .30 & -.19 & .08 & -.07 & -.04 & -.13 & .06 & .00 & .16 \\
\hline 26 Speed of promotion & .17 & .14 & -.16 & -.19 & -.31 & -.10 & -.05 & -.01 & -.01 & .02 & .02 & .09 \\
\hline 27 Gender & 1.50 & .50 & -.08 & .00 & & -.14 & & & -.08 & -.37 & & -.62 \\
\hline
\end{tabular}

1: Values between 0.08 et 0.10 (inclusive) are significant at $(\mathrm{p}<=0.05)$. Values above 0.10 are significant at $(\mathrm{p}<=0.01)$ 
Table 2: Correlation Table (cont'd)

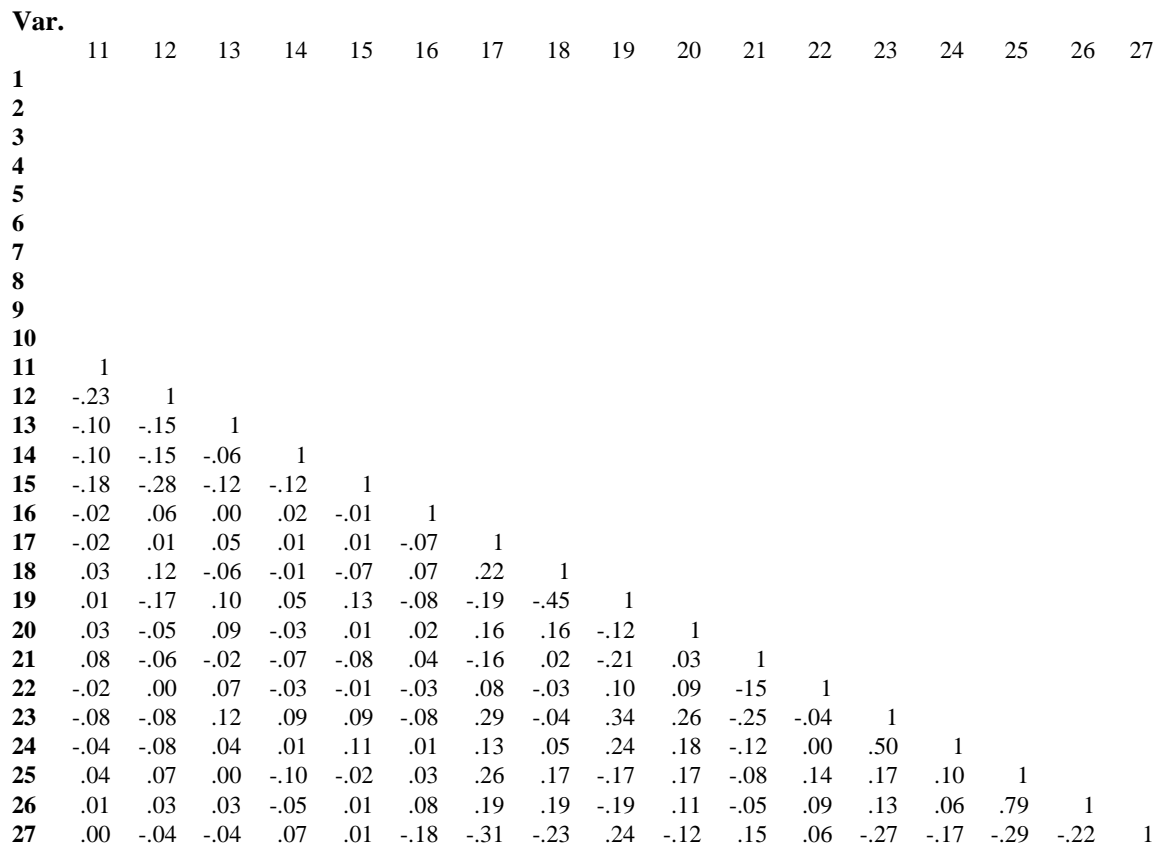


Table 3: Hierarchical Regression Analysis Predicting Career Success (Control Variables)

\begin{tabular}{lccccc}
\hline \hline Determinant & & Salary & $\begin{array}{c}\text { Hierarchical } \\
\text { Level }\end{array}$ & $\begin{array}{c}\text { Number of } \\
\text { Promotions }\end{array}$ & $\begin{array}{c}\text { Speed of } \\
\text { Promotion }\end{array}$ \\
\hline Control Variables & $\mathrm{R}^{2}$ & $7.0 \%$ & $2.5 \%$ & $18.9 \%$ & $9.7 \%$ \\
Gender (Men=1; Women=2) & $\mathrm{R}^{2}$ & $12.7 \%$ & $4.8 \%$ & $21.8 \%$ & $12.3 \%$ \\
\hline & $\Delta \mathrm{R}^{2}$ & $5.7 \%$ & $2.3 \%$ & $2.9 \%$ & $2.4 \%$ \\
& $\mathrm{~F}$ & $33.9 * * *$ & $12.9 * * *$ & $19.2 * * *$ & $14.5 * * *$ \\
& Beta & $-0.25^{* * *}$ & $-0.16^{* * *}$ & $-0.17 * * *$ & $-0.16^{* * * *}$ \\
\hline \hline
\end{tabular}

$*(\mathrm{p}<=0.05) ; \quad * *(\mathrm{p}<=0.01) ; * * *(\mathrm{p}<=0.001)$

All the $\mathrm{R}^{2}$ are adjusted 
Table 4: Hierarchical Regression Analysis Results for Men and Women Career Success

\begin{tabular}{|c|c|c|c|c|c|c|}
\hline \multirow[t]{2}{*}{ Determinant } & \multicolumn{3}{|c|}{ Salary } & \multicolumn{3}{|c|}{ Hierarchical Level } \\
\hline & Total & Men & Women & Total & Men & Women \\
\hline Years on labor market & $.25 * * *$ & $.30 * * *$ & .15 & $.14^{*}$ & .14 & .18 \\
\hline Seniority in the organization & .07 & -.03 & -.05 & -.01 & .10 & -.15 \\
\hline Seniority in the job & -.04 & -.09 & .02 & -.07 & -.03 & -.10 \\
\hline Job category (Staff vs. Line) & $-.10 * *$ & -.08 & -.10 & $-.13 * *$ & -.08 & $-.17 * *$ \\
\hline Level of education & $.47 * * *$ & $.46^{* * *}$ & $.55^{* * *}$ & $.18 * * *$ & $.20 * *$ & .15 \\
\hline Number of employers so far & $-.08^{*}$ & $-.13 * *$ & -.04 & -.05 & -.03 & -.08 \\
\hline Living alone & .00 & -.08 & .06 & -.06 & .01 & -.05 \\
\hline Married & .04 & $-.16^{* *}$ & .09 & .04 & -.08 & .08 \\
\hline Dependents & $.13 * * *$ & .03 & -.02 & .01 & -.09 & -.07 \\
\hline Farmer & -.10 & -.06 & -.13 & -.13 & -.15 & .07 \\
\hline Laborer & -.06 & .03 & -.16 & -.09 & -.16 & .19 \\
\hline Office worker & .04 & .06 & .03 & -.08 & -.15 & .05 \\
\hline Professional / Executive & .01 & .03 & -.01 & -.09 & -.14 & -.10 \\
\hline Entrepreneur & -.03 & -.02 & -.09 & .01 & -.14 & .25 \\
\hline Number of hours worked/week & $.17 * * *$ & .09 & $.18 * * *$ & .10 & .11 & .09 \\
\hline Overtime prepared to work & -.05 & -.07 & $-.11 *$ & .02 & -.06 & .05 \\
\hline Link (performance/reward) & .05 & .00 & .08 & $.14 * *$ & .03 & $.25^{* * *}$ \\
\hline Sector (public/private) & $.15^{* * * *}$ & $.26 * * *$ & .07 & $.23 * * *$ & .18 & $.27 * * *$ \\
\hline Amount of budget managed & $.26 * * *$ & $.30 * * *$ & $.18 * * *$ & $.17 * * *$ & $.19 * *$ & .04 \\
\hline Responsibility for admin. unit & $.10^{* *}$ & -.06 & -.07 & -.09 & $.15^{*}$ & .04 \\
\hline Number of people supervised & $-.08 *$ & -.08 & .01 & -.01 & .10 & $.18^{* *}$ \\
\hline$\overline{\mathrm{R}^{2}}$ & $61.7 \%$ & $63.7 \%$ & $60.9 \%$ & $24.6 \%$ & $29.5 \%$ & $28.7 \%$ \\
\hline $\mathrm{R}^{2}$ adjusted & $59.2 \%$ & $59.1 \%$ & $55.7 \%$ & $20.0 \%$ & $20.6 \%$ & $19.3 \%$ \\
\hline $\mathrm{F}$ & $26.5^{* * *}$ & $13.9 * * *$ & $11.8 * * *$ & $5.4 * * *$ & $3.3 * * *$ & $2.7 * * *$ \\
\hline
\end{tabular}

$*(\mathrm{p}<=0.05) ; * *(\mathrm{p}<=0.01) ; * * *(\mathrm{p}<=0.001)$ 
Table 4: Hierarchical Regression Analysis Results for Men and Women Career Success (cont'd)

\begin{tabular}{|c|c|c|c|c|c|c|}
\hline \multirow[t]{2}{*}{ Determinant } & \multicolumn{3}{|c|}{ Number of Promotions } & \multicolumn{3}{|c|}{ Speed of Promotion } \\
\hline & Total & Men & Women & Total & Men & Women \\
\hline Years on labor market & .00 & .15 & $.22 *$ & .01 & -.15 & $.26^{* *}$ \\
\hline Seniority in the organization & $.37 * * *$ & $.42 * * *$ & $.31 * * *$ & $-.13 *$ & -.08 & $-.23 * *$ \\
\hline Seniority in the job & $-.28 * * *$ & $-.20 * *$ & $-.39 * * *$ & $-.26 * * *$ & $-.17 *$ & $-.39 * * *$ \\
\hline Job category (Staff vs. Line) & -.04 & -.05 & -.03 & -.01 & -.01 & -.01 \\
\hline Level of education & .00 & -.04 & .00 & .00 & .00 & -.03 \\
\hline Number of employers so far & -.07 & .00 & $-.23 * *$ & -.06 & .05 & $-.29 * *$ \\
\hline Living alone & .06 & -.02 & .10 & .08 & .00 & .07 \\
\hline Married & .03 & .00 & .04 & .03 & .04 & .04 \\
\hline Dependents & .07 & -.05 & .08 & .06 & -.02 & .07 \\
\hline Farmer & .00 & .11 & -.06 & .01 & .12 & -.11 \\
\hline Laborer & -.02 & .09 & -.07 & -.02 & .11 & -.19 \\
\hline Office worker & -.03 & .03 & -.05 & -.01 & .09 & -.10 \\
\hline Professional / Executive & -.05 & -.02 & -.01 & -.10 & -.08 & .07 \\
\hline Entrepreneur & .00 & .10 & -.04 & -.02 & .11 & -.14 \\
\hline Number of hours worked/week & $.12 * *$ & $.20 * *$ & .01 & $.11^{*}$ & $.20 * *$ & -.04 \\
\hline Overtime prepared to work & .06 & .01 & .09 & .06 & .05 & .06 \\
\hline Link (performance/reward) & -.04 & -.04 & -.04 & -.03 & .00 & -.03 \\
\hline Sector (public/private) & -.03 & .03 & -.12 & -.05 & -.01 & -.14 \\
\hline Amount of budget managed & .06 & .06 & -.01 & .03 & .02 & -.01 \\
\hline Responsibility for admin. unit & -.03 & .01 & .00 & -.07 & -.06 & -.03 \\
\hline Number of people supervised & $.13^{* *}$ & .12 & $.20^{* *}$ & $.11^{*}$ & .13 & .10 \\
\hline $\mathrm{R}^{2}$ & $27.6 \%$ & $29.3 \%$ & $31.5 \%$ & $16.9 \%$ & $20.4 \%$ & $22.9 \%$ \\
\hline $\mathrm{R}^{2}$ adjusted & $22.8 \%$ & $20.4 \%$ & $22.3 \%$ & $11.4 \%$ & $10.3 \%$ & $12.5 \%$ \\
\hline $\mathrm{F}$ & $6.13^{* * *}$ & $3.3 * * *$ & $3.4^{* * *}$ & $3.2 * * *$ & $2.0 * *$ & $2.2 * *$ \\
\hline
\end{tabular}

$*(\mathrm{p}<=0.05) ; *(\mathrm{p}<=0.01) ; * * *(\mathrm{p}<=0.001)$ 
Table 5: Hierarchical Regression Analysis Predicting Career Success (Human Capital Model)

\begin{tabular}{|c|c|c|c|c|c|}
\hline \multicolumn{2}{|l|}{ Determinant } & \multirow{2}{*}{$\begin{array}{c}\text { Salary } \\
6.1 \%\end{array}$} & \multirow{2}{*}{$\begin{array}{c}\begin{array}{c}\text { Hierarchical } \\
\text { Level }\end{array} \\
1.9 \%\end{array}$} & \multirow{2}{*}{$\begin{array}{c}\begin{array}{c}\text { Number of } \\
\text { Promotions }\end{array} \\
19.5 \%\end{array}$} & \multirow{2}{*}{$\begin{array}{c}\text { Speed of } \\
\text { Promotion } \\
8.6 \%\end{array}$} \\
\hline Control Variables & $\mathrm{R}^{2}$ & & & & \\
\hline & $\mathrm{R}^{2}$ & $39.8 \%$ & $11.6 \%$ & $20.4 \%$ & $9.4 \%$ \\
\hline & $\Delta \mathrm{R}^{2}$ & $33.7 \%$ & $9.7 \%$ & $0.9 \%$ & $0.8 \%$ \\
\hline & $\mathrm{F}$ & $136.8 * * *$ & $26.6 * * *$ & 2.6 & 2.0 \\
\hline \multirow[t]{4}{*}{ Gender (Men=1; Women=2) } & $\mathrm{R}^{2}$ & $45.9 \%$ & $14.2 \%$ & $22.7 \%$ & $11.4 \%$ \\
\hline & $\Delta \mathrm{R} 2$ & $6.1 \%$ & $2.6 \%$ & $2.3 \%$ & $2.0 \%$ \\
\hline & $\mathrm{F}$ & $54.9 * * *$ & $14.3 * *$ & $14.2 * * *$ & $10.7 * * *$ \\
\hline & Beta & $-0.25 * * *$ & $-0.16 * * *$ & $-0.15 * * *$ & $-0.14 * * *$ \\
\hline
\end{tabular}

$*(\mathrm{p}<=0.05) ; \quad * *(\mathrm{p}<=0.01) ; \quad * * *(\mathrm{p}<=0.001)$

All the $\mathrm{R}^{2}$ are adjusted 
Table 6: Hierarchical Regression Analysis Predicting Career Success (Family Context Model)

\begin{tabular}{|c|c|c|c|c|c|}
\hline \multicolumn{2}{|l|}{ Determinant } & \multirow{2}{*}{$\begin{array}{c}\text { Salary } \\
7.7 \%\end{array}$} & \multirow{2}{*}{$\begin{array}{c}\begin{array}{c}\text { Hierarchical } \\
\text { Level }\end{array} \\
2.5 \%\end{array}$} & \multirow{2}{*}{$\begin{array}{c}\begin{array}{c}\text { Number of } \\
\text { Promotions }\end{array} \\
19.0 \%\end{array}$} & \multirow{2}{*}{$\begin{array}{c}\begin{array}{c}\text { Speed of } \\
\text { Promotion }\end{array} \\
9.9 \%\end{array}$} \\
\hline Control Variables & $\mathrm{R}^{2}$ & & & & \\
\hline Family Context & $\mathrm{R}^{2}$ & $9.9 \%$ & $2.9 \%$ & $20.5 \%$ & $10.8 \%$ \\
\hline & $\Delta \mathrm{R}^{2}$ & $2.2 \%$ & $0.4 \%$ & $1.5 \%$ & $0.9 \%$ \\
\hline & $\mathrm{F}$ & $4.16 * *$ & 0.70 & $3.06^{*}$ & 1.78 \\
\hline \multirow[t]{4}{*}{ Gender $($ Men=1; Women=2) } & $\mathrm{R}^{2}$ & $13.0 \%$ & $5.3 \%$ & $22.1 \%$ & $12.5 \%$ \\
\hline & $\Delta \mathrm{R}^{2}$ & $3.1 \%$ & $2.4 \%$ & $1.6 \%$ & $1.7 \%$ \\
\hline & $\mathrm{F}$ & $18.5^{* * *}$ & $12.8 * * *$ & $10.1^{* *}$ & $9.9^{* *}$ \\
\hline & Beta & $-0.23 * * *$ & $-0.20 * * *$ & $-0.16 * * *$ & $-0.17 * * *$ \\
\hline
\end{tabular}

$*(\mathrm{p}<=0.05) ; \quad * *(\mathrm{p}<=0.01) ; \quad * * *(\mathrm{p}<=0.001)$

All the $\mathrm{R}^{2}$ are adjusted 
Table 7: Hierarchical Regression Analysis Predicting Career Success (Socioeconomic Origin Model)

\begin{tabular}{|c|c|c|c|c|c|}
\hline \multicolumn{2}{|l|}{ Determinant } & \multirow{2}{*}{$\begin{array}{c}\text { Salary } \\
7.0 \%\end{array}$} & \multirow{2}{*}{$\begin{array}{c}\begin{array}{c}\text { Hierarchical } \\
\text { Level }\end{array} \\
2.5 \%\end{array}$} & \multirow{2}{*}{$\begin{array}{c}\begin{array}{c}\text { Number of } \\
\text { Promotions }\end{array} \\
18.9 \%\end{array}$} & \multirow{2}{*}{$\begin{array}{c}\begin{array}{c}\text { Speed of } \\
\text { Promotion }\end{array} \\
9.8 \%\end{array}$} \\
\hline Control Variables & $\mathrm{R}^{2}$ & & & & \\
\hline Socioeconomic Origin & $\mathrm{R}^{2}$ & $11.3 \%$ & $4.4 \%$ & $20.1 \%$ & $11.1 \%$ \\
\hline & $\Delta \mathrm{R}^{2}$ & $4.3 \%$ & $1.9 \%$ & $1.1 \%$ & $1.3 \%$ \\
\hline & $\mathrm{F}$ & $3.6 * * *$ & 1.5 & 1.0 & 1.1 \\
\hline \multirow[t]{4}{*}{ Gender (Men=1; Women=2) } & $\mathrm{R}^{2}$ & $16.9 \%$ & $6.9 \%$ & $22.8 \%$ & $13.4 \%$ \\
\hline & $\Delta \mathrm{R}^{2}$ & $5.6 \%$ & $2.5 \%$ & $2.7 \%$ & $2.3 \%$ \\
\hline & $\mathrm{F}$ & $34.8 * * *$ & $13.9 * * *$ & $17.8 * * *$ & $13.6^{* * *}$ \\
\hline & Beta & $-0.24 * * *$ & $-0.16 * * *$ & $-0.17 * * *$ & $-0.16 * * *$ \\
\hline
\end{tabular}

$*(\mathrm{p}<=0.05) ; * *(\mathrm{p}<=0.01) ; * * *(\mathrm{p}<=0.001)$

All the $\mathrm{R}^{2}$ are adjusted 
Table 8: Hierarchical Regression Analysis Predicting Career Success (Values and Motivations Model)

\begin{tabular}{|c|c|c|c|c|c|}
\hline \multicolumn{2}{|l|}{ Determinant } & \multirow{2}{*}{$\begin{array}{c}\text { Salary } \\
8.1 \%\end{array}$} & \multirow{2}{*}{$\begin{array}{c}\begin{array}{c}\text { Hierarchical } \\
\text { Level }\end{array} \\
3.5 \%\end{array}$} & \multirow{2}{*}{$\begin{array}{c}\begin{array}{c}\text { Number of } \\
\text { Promotions }\end{array} \\
20.5 \%\end{array}$} & \multirow{2}{*}{$\begin{array}{c}\begin{array}{c}\text { Speed of } \\
\text { Promotion }\end{array} \\
10.3 \%\end{array}$} \\
\hline Control Variables & $\mathrm{R}^{2}$ & & & & \\
\hline Values and Motivations & $\mathrm{R}^{2}$ & $16.3 \%$ & $4.5 \%$ & $25.6 \%$ & $15.7 \%$ \\
\hline & $\Delta \mathrm{R}^{2}$ & $8.2 \%$ & $1.0 \%$ & $5.1 \%$ & $5.4 \%$ \\
\hline & $\mathrm{F}$ & $15.4^{* * * *}$ & 1.7 & $10.6^{* * *}$ & $9.8 * * *$ \\
\hline \multirow[t]{4}{*}{ Gender $($ Men=1; Women=2) } & $\mathrm{R}^{2}$ & $20.6 \%$ & $5.9 \%$ & $26.5 \%$ & $16.4 \%$ \\
\hline & $\Delta \mathrm{R}^{2}$ & $4.3 \%$ & $1.4 \%$ & $0.9 \%$ & $0.7 \%$ \\
\hline & $\mathrm{F}$ & $25.1 * * *$ & $6.9 * *$ & $5.6^{*}$ & 3.7 \\
\hline & Beta & $-0.23 * * *$ & $-0.13 * *$ & $-0.11 * *$ & $-0.09 *$ \\
\hline
\end{tabular}

$*(\mathrm{p}<=0.05) ; \quad * *(\mathrm{p}<=0.01) ; * * *(\mathrm{p}<=0.001)$

All the $\mathrm{R}^{2}$ are adjusted 
Table 9: Hierarchical Regression Analysis Predicting Career Success (Sector-based and Organizational Model)

\begin{tabular}{|c|c|c|c|c|c|}
\hline \multicolumn{2}{|l|}{ Determinant } & \multirow{2}{*}{$\begin{array}{c}\text { Salary } \\
7.8 \%\end{array}$} & \multirow{2}{*}{$\begin{array}{c}\begin{array}{c}\text { Hierarchical } \\
\text { Level }\end{array} \\
3.0 \%\end{array}$} & \multirow{2}{*}{$\begin{array}{c}\text { Number of } \\
\text { Promotions }\end{array}$} & \multirow{2}{*}{$\begin{array}{c}\begin{array}{c}\text { Speed of } \\
\text { Promotion }\end{array} \\
10.2 \%\end{array}$} \\
\hline Control Variables & $\mathrm{R}^{2}$ & & & & \\
\hline Sector and Organization & $\mathrm{R}^{2}$ & $34.1 \%$ & $14.9 \%$ & $21.4 \%$ & $13.0 \%$ \\
\hline & $\Delta \mathrm{R}^{2}$ & $26.3 \%$ & $11.9 \%$ & $3.6 \%$ & $2.8 \%$ \\
\hline & $\mathrm{F}$ & $44.5 * * *$ & $15.4 * * *$ & $4.9 * * *$ & $3.4 * *$ \\
\hline \multirow[t]{4}{*}{ Gender (Men=1; Women=2) } & $\mathrm{R}^{2}$ & $42.9 \%$ & $18.4 \%$ & $23.1 \%$ & $14.1 \%$ \\
\hline & $\Delta \mathrm{R}^{2}$ & $8.8 \%$ & $3.5 \%$ & $1.7 \%$ & $1.1 \%$ \\
\hline & $\mathrm{F}$ & $68.4 * * *$ & $19.0 * * *$ & $9.4 * *$ & $5.4^{*}$ \\
\hline & Beta & $-0.32 * * *$ & $-0.20 * * *$ & $-0.14 * *$ & $-0.11 * *$ \\
\hline
\end{tabular}

$*(\mathrm{p}<=0.05) ; \quad * *(\mathrm{p}<=0.01) ; \quad * * *(\mathrm{p}<=0.001)$

All the $\mathrm{R}^{2}$ are adjusted 
Table 10: Hierarchical Regression Analysis Predicting Career Success (Global Model)

\begin{tabular}{|c|c|c|c|c|c|}
\hline \multicolumn{2}{|l|}{ Determinants } & \multirow{2}{*}{$\begin{array}{l}\text { Salary } \\
9.1 \%\end{array}$} & \multirow{2}{*}{$\begin{array}{c}\begin{array}{c}\text { Hierarchical } \\
\text { Level }\end{array} \\
3.9 \%\end{array}$} & \multirow{2}{*}{$\begin{array}{c}\begin{array}{r}\text { Number of } \\
\text { Promotions }\end{array} \\
20.8 \%\end{array}$} & \multirow{2}{*}{$\begin{array}{c}\begin{array}{c}\text { Speed of } \\
\text { Promotion }\end{array} \\
10.0 \%\end{array}$} \\
\hline $\begin{array}{l}\text { (Step 1) } \\
\text { Control Variables } \\
\text { (Step 2) }\end{array}$ & $\mathrm{R}^{2}$ & & & & \\
\hline \multirow{3}{*}{ Human Capital } & $\mathrm{R}^{2}$ & $44.0 \%$ & $13.8 \%$ & $21.2 \%$ & $10.5 \%$ \\
\hline & $\Delta \mathrm{R}^{2}$ & $34.9 \%$ & $9.9 \%$ & $0.4 \%$ & $0.5 \%$ \\
\hline & $\mathrm{F}$ & $113.30^{* * *}$ & $20.78 * * *$ & 0.91 & 0.85 \\
\hline \multirow[t]{3}{*}{$\begin{array}{l}\text { (Step 3) } \\
\text { Family Context }\end{array}$} & $\mathrm{R}^{2}$ & $47.5 \%$ & $14.7 \%$ & $22.5 \%$ & $11.7 \%$ \\
\hline & $\Delta \mathrm{R}^{2}$ & $3.5 \%$ & $0.90 \%$ & $1.3 \%$ & $1.2 \%$ \\
\hline & $\mathrm{F}$ & $8.03 * * *$ & 1.32 & 1.90 & 1.67 \\
\hline \multirow[t]{3}{*}{$\begin{array}{l}\text { (Step 4) } \\
\text { Socioeconomic origin }\end{array}$} & $\mathrm{R}^{2}$ & $49.6 \%$ & $16.2 \%$ & $23.1 \%$ & $12.8 \%$ \\
\hline & $\Delta \mathrm{R}^{2}$ & $2.1 \%$ & $1.5 \%$ & $0.6 \%$ & $1.1 \%$ \\
\hline & $\mathrm{F}$ & $2.03^{*}$ & 0.87 & 0.37 & 0.64 \\
\hline \multirow[t]{3}{*}{$\begin{array}{l}\text { (Step 5) } \\
\text { Values and motivations }\end{array}$} & $\mathrm{R}^{2}$ & $53.7 \%$ & $18.6 \%$ & $25.3 \%$ & $15.0 \%$ \\
\hline & $\Delta \mathrm{R}^{2}$ & $4.1 \%$ & $2.4 \%$ & $2.2 \%$ & $2.2 \%$ \\
\hline & F & $10.52 * * *$ & $3.49^{*}$ & $3.46 * *$ & $2.93^{*}$ \\
\hline \multirow[t]{3}{*}{$\begin{array}{l}\text { (Step 6) } \\
\text { Sector and organization }\end{array}$} & $R^{2}$ & $61.7 \%$ & $24.6 \%$ & $27.6 \%$ & $16.9 \%$ \\
\hline & $\Delta \mathrm{R}^{2}$ & $8.0 \%$ & $6.0 \%$ & $2.3 \%$ & $1.9 \%$ \\
\hline & 1 & $17.89 * * *$ & $6.78 * * *$ & $2.74 *$ & 1.92 \\
\hline \multirow[t]{4}{*}{$\begin{array}{l}\text { (Step 7) } \\
\text { Gender }\end{array}$} & $\mathrm{R}^{2}$ & $64.8 \%$ & $26.6 \%$ & $27.8 \%$ & $16.9 \%$ \\
\hline & $\Delta \mathrm{R}^{2}$ & $3.1 \%$ & $2.0 \%$ & $0.2 \%$ & $0.0 \%$ \\
\hline & F & $29.99 * * *$ & $9.18^{* *}$ & 0.67 & 0.15 \\
\hline & Beta & $-0.24 * * *$ & $-0.21 * * *$ & -0.05 & -0.03 \\
\hline
\end{tabular}

$*(\mathrm{p}<=0.05) ; \quad * *(\mathrm{p}<=0.01) ; \quad * * *(\mathrm{p}<=0.001)$ 


\section{Liste des publications au CIRANO *}

\section{Cahiers CIRANO / CIRANO Papers (ISSN 1198-8169)}

96c-1 Peut-on créer des emplois en réglementant le temps de travail ? / Robert Lacroix

95c-2 Anomalies de marché et sélection des titres au Canada / Richard Guay, Jean-François L'Her et Jean-Marc Suret

95c-1 La réglementation incitative / Marcel Boyer

94c-3 L'importance relative des gouvernements : causes, conséquences et organisations alternative / Claude Montmarquette

94c-2 Commercial Bankruptcy and Financial Reorganization in Canada / Jocelyn Martel

94c-1 Faire ou faire faire : La perspective de l'économie des organisations / Michel Patry

\section{Série Scientifique / Scientific Series (ISSN 1198-8177)}

98s-09 Managerial Career Success in Canadian Organizations: Is Gender a Determinant? / Denis Chênevert et Michel Tremblay

98s-08 Job Characteristics and the Form of Compensation / W. Bentley MacLeod et Daniel Parent

98s-07 Technological Capability and Productivity Growth: An Industrialized / Industrializing Country Comparison / Pierre J. Tremblay

98s-06 L'évolution du taux d'activité des femmes au Canada, 1976-1994 : Une analyse de cohortes / Paul Beaudry et Thomas Lemieux

98s-05 Dix exemples de rentabilité financière liés à une saine gestion environnementale / Paul Lanoie et Georges A. Tanguay

98s-04 Effects of Workers' Compensation: A Survey / Bernard Fortin et Paul Lanoie

98s-03 Dépendance à l'égard de l'aide sociale et réforme de la sécurité du revenu / Bernard Fortin

98s-02 Risk Aversion, Intertemporal Substitution, and Option Pricing / René Garcia et Éric Renault

98s-01 Learning-by-Doing and Strategic Trade Policy / Hassan Benchekroun, Ngo Van Long et Huilan Tian

97s-42 Sector-Specific On-the-Job Training: Evidence from U.S. Data / Lars Vilhuber

97s-41 Competition and Access in Electricity Markets: ECPR, Global Price Cap, and Auctions / Marcel Boyer et Jacques Robert

97s-40 Strategic Adoption of a New Technology under Uncertain Implementation / Marcel Boyer et Séverine Clamens

97s-39 Seasonal Adjustment and Volatility Dynamics / Eric Ghysels, Clive W.J. Granger et Pierre L. Siklos

97s-38 How Do Young People Choose College Majors? / Claude Montmarquette, Kathy Cannings et Sophie Mahseredjian

97s-37 A General Equilibrium Analysis of the Evolution of the Canadian Service Productivity / Pierre Mohnen et Thijs ten Raa

* Vous pouvez consulter la liste complète des publications du CIRANO et les publications elles-mêmes sur notre site World Wide Web à l'adresse suivante :

http://www.cirano.umontreal.ca/publication/page1.html 